\title{
Pengaruh Pemberian Suplementasi Besi (Fe) Dosis Tinggi Terhadap Kondisi Sel Beta Pankreas Pada Tikus Putih (Rattus norvegicus) Strain Wistar Bunting
}

\author{
Alfin Septia Putri Aldi ${ }^{1)}$, Umi Kalsum², Fatmawati $^{3}$ \\ ${ }^{1)}$ Program Studi S1 Kebidanan, Fakultas Kedokteran Universitas Brawijaya Malang, e-mail : \\ alfinseptia7@gmail.com, Tlp: +6281357578877 \\ ${ }^{2}$ Laboratorium Farmakologi, Fakultas Kedokteran Universitas Brawijaya Malang, Email: \\ dr.umikalsum@gmail.com \\ ${ }^{3}$ Program Studi S1 Kebidanan, Fakultas Kedokteran Universitas Brawijaya Malang, Email: \\ fatmawatibetty26@gmail.com
}

\begin{abstract}
During pregnancy, pregnant women need various nutrients. One of the nutrients need is iron. Iron functions for the formation of hemoglobin. Excess iron can increase free radicals and trigger oxidative stress. The aim of this study was to determine the effect of high doses of iron supplementation on the condition of the beta cells pancreas of the pregnant wistar white rat (Rattus novergicus). The condition of pancreatic beta cells seen is the number of beta cells calculated using a microscope with 400x magnification. Iron supplementation was given 18 days with 3 different doses $(0.54 \mathrm{mg}, 1.08 \mathrm{mg}$, and $2.16 \mathrm{mg})$. The number of pancreatic beta cells differed significantly between the control and treatment groups $(p=$ 0,000 ), the mean number of the smallest pancreatic beta cells in the group (P3) 12,17. Iron supplementation can reduce the number of pancreatic beta cells in pregnant wistar white rat (Rattus novergicus).
\end{abstract}

Keywords: Iron suplementation, number of pancreatic beta cells, oxidative stress

\begin{abstract}
ABSTRAK
Selama masa kehamilan, ibu hamil membutuhkan berbagai zat gizi. Salah satu zat gizi yang diperlukan yaitu zat besi. Zat besi berfungsi untuk pembentukan hemoglobin. Kelebihan zat besi dapat meningkatkan radikal bebas dan memicu stress oksidatif. Penelitian ini bertujuan untuk mengetahui efek pemberian suplementasi besi dosis tinggi terhadap kondisi sel beta pankreas tikus putih (Rattus novergicus) strain wistar bunting. Kondisi sel beta pankreas yang dilihat adalah jumlah sel beta dihitung menggunakan mikroskop cahaya dengan perbesaran 400x. Suplementasi besi diberikan 18 hari dengan 3 dosis berbeda $(0,54 \mathrm{mg}$, $1,08 \mathrm{mg}$, dan 2,16mg). Jumlah sel beta pankreas berbeda signifikan antar kelompok kontrol dan perlakuan $(p=0,000)$, rerata jumlah sel beta pankreas terkecil pada kelompok (P3)
\end{abstract}


12,17. Suplementasi besi dapat menurunkan jumlah sel beta pankreas pada tikus putih (Rattus novergicus) strain wistar bunting.

Kata Kunci: Suplementasi besi , jumlah sel beta pankreas, stress oksidatif

`Korespondensi: Alfin Septia Putri Aldi. Surel: alfinseptia7@gmail.com

\section{PENDAHULUAN}

Selama masa kehamilan terjadi perubahan pada sistem kardiovaskular ibu. Volume darah juga mengalami peningkatan sejumlah $50 \%$ dan massa eritrosit meningkat 20-30\%. Pertambahan volume darah meliputi eritrosit dan plasma. Plasma darah yang lebih banyak dibandingkan eritrosit dapat mengurangi hemoglobin 1 .

Salah satu zat gizi yang berpengaruh dalam kehamilan untuk pembentukan hemoglobin adalah zat besi. Pemberian suplemen tablet besi selama masa kehamilan dapat meningkatkan status besi ibu. Bila selama kehamilan seorang ibu mengalami kekurangan zat besi bisa mengakibatkan anemia dan hipoksia, namun jika mengalami kelebihan zat besi bisa bersifat toksik karena zat besi bersifat reaktif dan dapat terakumulasi di organ tubuh seperti liver, jantung, kulit, dan pankreas ${ }^{2}$.

Menurut hasil Riskesdas tahun 2018, prevalensi anemia pada ibu hamil di Indonesia adalah 48,9\%. Pemberian suplementasi tablet $\mathrm{Fe}$ yang dilaksanakan di Indonesia yaitu $73,2 \%$. Zat besi berperan dalam pembentukan hemolgobin. Di dalam tubuh, hemoglobin akan difagosit di dalam hati, limpa, dan sumsum tulang serta diubah menjadi bentuk globin dan heme ${ }^{3}$.

Zat besi yang terlalu banyak dalam tubuh bisa membuat reaksi reaktif, sifat reaktif tersebut dapat dengan mudah berikatan dengan radikal bebas dan menyebabkan stress oksidatif yang mempunyai potensi untuk merusak sel, organ, dan jaringan yang ada di dalam tubuh ${ }^{4}$.

Kelebihan zat besi pada pankreas juga dapat mengakibatkan stress oksidatif di sel beta yang diikuti dengan kematian sel, defisiensi insulin, dan intolerasi glukosa ${ }^{5}$. Kerusakan sel beta pankreas menyebabkan tubuh tidak dapat menghasilkan insulin sehingga dapat mengakibatkan tingginya kadar glukosa darah atau hiperglikemia. Kondisi hiperglikemia dapat menghasilkan pembentukan reactive oxygen species (ROS). $\mathrm{Di}$ mana produksi ROS yang berlebih dapat menyebabkan stres oksidatif dan memperparah kerusakan sel beta pankreas ${ }^{6}$.

Berdasarkan latar belakang di atas, mendorong untuk dilakukan penelitian mengenai pengaruh suplementasi besi dosis tinggi terhadap kondisi sel beta pankreas tikus putih bunting.

\section{METODE PENELITIAN}

\section{Sampel dan Suplementasi Besi}

Sampel penelitian ini adalah tikus putih (Rattus Norvegicus) strain wistar bunting ( $\mathrm{n}=24)$ yang memenuhi kriteria inklusi yaitu tikus betina, bunting, usia minimal 8-10 minggu, berat tikus 150250 gram, sehat dengan bulu berwarna putih, tidak ada abnormalitas yang tampak, dan bergerak aktif. Rancangan penelitian yang digunakan adalah Post Test Only with Control Group Design. Sampel dibagi menjadi 4 kelompok, yaitu kelompok kontrol dan 3 kelompok perlakuan. Lama perlakuan yaitu 18 hari dengan 3 dosis yang berbeda yaitu P1 $(0,54 \mathrm{mg}), \mathrm{P} 2$ 
$(1,08 \mathrm{mg})$, dan P3 $(2,16 \mathrm{mg})$. Masingmasing kelompok terdiri dari 6 ekor tikus.

\section{Penghitungan Jumlah Sel Beta Pankreas}

Pewarnaan sel beta pankreas dengan Hematoxilin-Eosin. Jumlah sel dihitung dengan mikroskop cahaya perbesaran 400x.

\section{Teknik Analisis Data}

Data disajikan dalam rata-rata \pm standar deviasi. Analisis data yang digunakan adalah One Way ANOVA. Jika terdapat perbedaan yang bermakna dilanjutkan dengan uji PostHoc Tuckey.

\section{HASIL PENELITIAN}

Hasil rerata jumlah sel beta pankreas kelompok kontrol dibanding perlakuan disajikan dalam Tabel 1.

Tabel 1. Rerata jumlah sel beta pankreas kelompok kontrol dibanding perlakuan

\begin{tabular}{|c|c|c|c|c|}
\hline Tikus & $\begin{array}{c}\text { Kontr } \\
\text { ol }\end{array}$ & P1 & P2 & P3 \\
\hline 1 & 135 & 73 & 36 & 15 \\
\hline 2 & 117 & 57 & 29 & 18 \\
\hline 3 & 146 & 78 & 34 & 9 \\
\hline 4 & 94 & 60 & 39 & 9 \\
\hline 5 & 191 & 55 & 43 & 10 \\
\hline 6 & 113 & 59 & 39 & 12 \\
\hline $\begin{array}{c}\text { Rerata } \\
\pm\end{array}$ & $\begin{array}{c}132,6 \\
7 \pm\end{array}$ & $\begin{array}{c}63,6 \\
7 \pm\end{array}$ & $\begin{array}{c}36,67 \\
\pm\end{array}$ & $\begin{array}{c}12,17 \\
\pm\end{array}$ \\
$\begin{array}{c}\text { Std.Devi } \\
\text { asi }\end{array}$ & $\begin{array}{c}33,80 \\
3\end{array}$ & $\begin{array}{c}9,45 \\
9\end{array}$ & $\begin{array}{c} \pm, 844 \\
3,656\end{array}$ \\
\hline
\end{tabular}

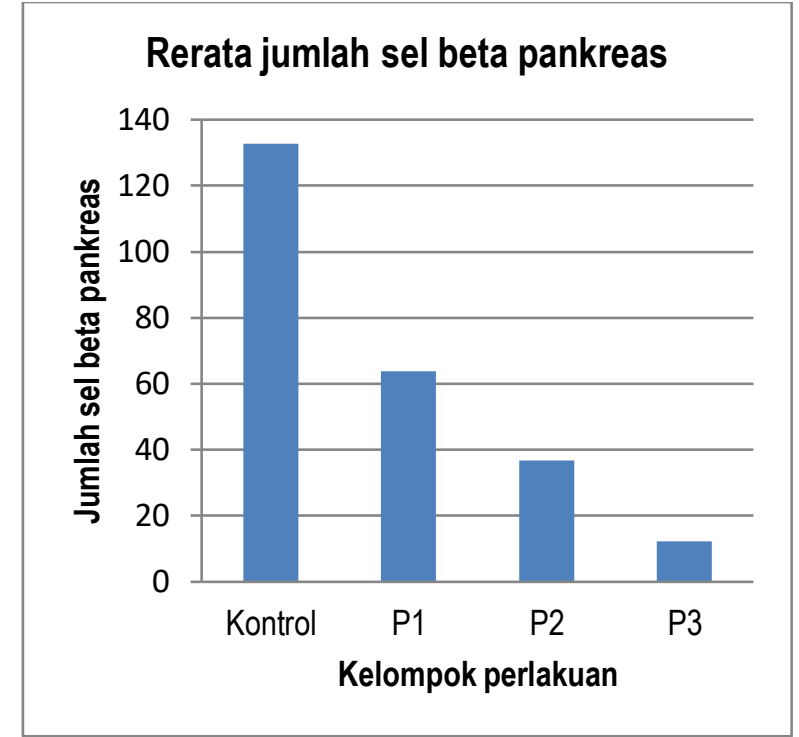

Gambar 1. Grafik rerata jumlah sel beta pankreas kelompok kontrol dan perlakuan1, 2 dan 3

Dari grafik tersebut, terlihat bahwa jumlah sel beta pankreas pada kelompok kontrol yang paling banyak yaitu 132,67. Pada kelompok yang diberi perlakuan, jumlah sel beta pankreas terus menurun dari P1 sampai P3 yaitu 63,67, 36,67, dan 12,17. Dari hasil uji statistik didapatkan hasil signifikansi $0,000(p<0,05)$. Hal ini berarti terdapat perbedaan yang bermakna antara pemberian suplementasi besi $(\mathrm{Fe})$ dosis tinggi terhadap jumlah sel beta pankreas.

Perbandingan jumlah sel beta pankreas antar kelompok dapat dilihat pada Gambar 2. 


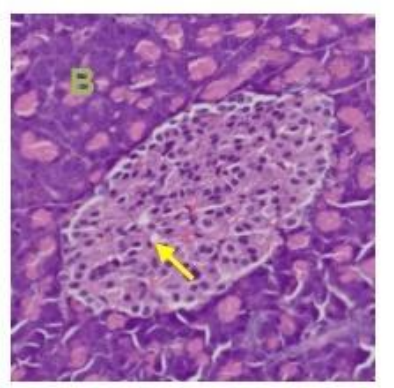

Kontrol

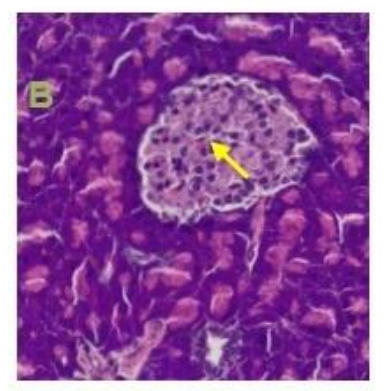

Perlakuan 1

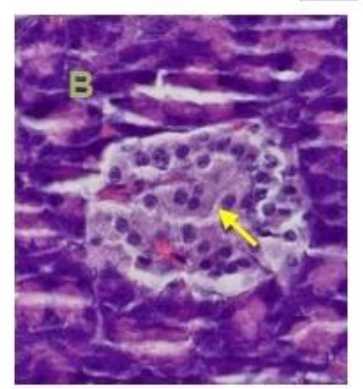

Perlakuan 2

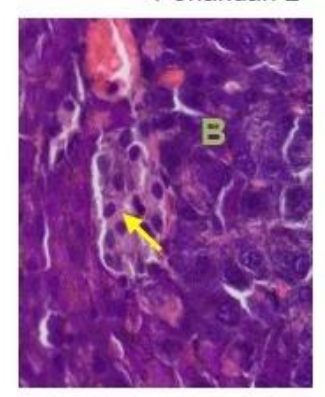

Perlakuan 3

\section{Gambar 2. Pankreas setiap kelompok perlakuan dengan pewarnaan HE perbesaran 400x $(=$ sel beta pankreas, $B=$ sel asiner)}

Berdasar gambar 1 terlihat bahwa adanya perbedaan kepadatan sel pada pankreas kelompok kontrol jika dibandingkan dengan kelompok perlakuan. Pada kelompok kontrol terlihat sel yang tersusun padat dan rapi. Pada kelompok kontrol, sel beta pankreas memenuhi pulau Langerhans dan dari ketiga kelompok perlakuan, perlakuan 3 memiliki jumlah sel beta yang paling sedikit. Hal ini menunjukkan pemberian suplementasi zat besi dapat menurunkan jumlah sel beta pankreas. Pada kelompok perlakuan 1 sampai 3 terdapat ruang kosong pada pulau Langerhans, hal ini menunjukkan adanya nekrosis pada sel beta pankreas, selain itu juga terdapat edema yang merupakan salah satu tanda sebelum terjadinya nekrosis.

\section{PEMBAHASAN}

Selama masa kehamilan, ibu hamil membutuhkan berbagai zat gizi.
Salah satu zat gizi yang diperlukan yaitu zat besi. Zat besi berfungsi untuk pembentukan hemoglobin. Pada keadaan sebelum hamil, seorang wanita dapat memenuhi kebutuhan akan zat besi dari makanan yang sehat dan seimbang. Namun, jika dalam masa kehamilan, kebutuhan akan zat besi dari makanan belum dapat mencukupi, diperlukan pemberian suplemen tablet besi.

Metabolisme zat besi di dalam tubuh terbagi menjadi 4 jalur. Jalur pertama yaitu berpusat pada transferin. Jalur yang kedua yaitu melalui sel yang memperoleh besi melalui penyerapan dari non-transferrin-bound iron (NTBI) yang bisa disebut besi bebas. Terdapat 3 transporter membran seluler yang berperan dalam penyerapan NTBI, yaitu divalent metal-ion transporter 1 (DMT1), Zrt- and Irt-like protein 14 (ZIP14) dan ZIP87.

ZIP14 memegang peranan penting dalam akumulasi besi di jaringan dalam bentuk NTBI. Di dalam model tikus dengan kelebihan zat besi, didapatkan defisiensi ZIP14 dapat mengurangi jumlah simpanan besi di liver dan pankreas. Jalur yang ketiga yaitu penyerapan zat besi dalam bentuk hemoglobin dan heme. Jalur keempat yaitu penyerapan zat besi sebagai protein ferritin 7 .

Besi dalam bentuk bebas membuat adanya kemungkinan reaksi redoks satu elektron. Hal ini dapat mengkatalisasi elektron tunggal $\mathrm{LOOH}$ menjadi LO yang merupakan salah satu bentuk radikal bebas. Radikal bebas dapat menghancurkan keseimbangan sistem biologi dengan menyebabkan kerusakan pada makromolekul (lipid, protein, karbohidrat, dan DNA) dan akhirnya menyebabkan kematian sel${ }^{8}$.

Sel beta sangat rentan terhadap stres oksidatif karena kurangnya enzim antioksidan Sel beta pankreas memiliki jumlah enzim antioksidan yang sedikit 
yaitu sekitar 50\% SOD dan 5\% GPx dan CAT dibandingkan dengan enzim antioksidan di liver. Hal ini membuat sel beta pankreas sangat sensitif terhadap ROS yang menandakan stres oksidatif ${ }^{9}$. Kondisi sel beta pankreas yang normal akan terlihat banyaknya jumlah sel beta di pulau Langerhans yang tersusun padat dan memadati pulau Langerhans. Namun, jika ada kerusakan pada sel beta pankreas akan terlihat adanya atrofi, kerusakan pada membran sel dan terjadi edema sebelum sel mengalami nekrosis ${ }^{10}$.

Jika terjadi kerusakan pada sel beta pankreas mengakibatkan tubuh tidak dapat memproduksi insulin sehingga kadar glukosa dalam darah akan meningkat (terjadi keadaan hiperglikemia). Kondisi hiperglikemi dapat menghasilkan pembentukan spesies oksigen reaktif (ROS). Produksi ROS yang berlebihan dapat mengakibatkan stres oksidatif dan memperparah kerusakan sel beta pankreas ${ }^{11}$.

Berdasar hasil statistik pada penelitian ini, $\quad(p=0.000)$ terdapat perbedaan yang bermakna antar kelompok kontrol dengan kelompok perlakuan yaitu terdapat pengaruh suplementasi zat besi terhadap menurunnya jumlah sel beta pankreas. $\mathrm{Hal}$ ini dapat ditunjukkan dengan semakin ditingkatkan dosis pemberian suplementasi zat besi, jumlah sel beta pankreas semakin menurun. Hal ini sesuai dengan pembahasan sebelumnya bahwa zat besi yang berlebih dapat memicu terjadinya stress oksidatif karena terdapat besi dalam bentuk bebas yang dapat meningkatkan produksi ROS. Adanya stress oksidatif dapat menyebabkan terjadinya kematian pada sel beta pankreas.

Pada penelitian yang dilakukan oleh Suarsana pada tahun 2010 menyatakan bahwa pemberian aloksan dapat menurunkan jumlah sel beta pankreas. Pemberian aloksan menyebabkan kondisi hiperglikemia pada tikus yang dapat meningkatkan ROS dan dapat terjadi stress oksidatif ${ }^{11}$.

Pada penelitian lain yang dilakukan oleh Mutiyani pada tahun 2013 menunjukkan diet tinggi karbohidrat dapat mempengaruhi jumlah sel beta pankreas dari 86,96 menjadi 45,05, hal ini dikarenakan adanya kondisi hiperglikemia. Kondisi hiperglikemia dapat memicu stress oksidatif yang dapat memicu apoptosis sel beta pankreas ${ }^{12}$.

Dengan adanya kerusakan sel beta pankreas yang diakibatkan oleh stress oksidatif dapat menyebabkan tubuh tidak dapat menghasilkan insulin, sehingga hal ini dapat menyebabkan tingginya kadar gula darah. Pada ibu hamil terjadi perubahan hormon yang meningkatkan resistensi insulin. Jika produksi insulin oleh sel beta pankreas tidak seimbang dapat terjadinya hiperglikemia yang memicu terjadinya diabetes melitus gestasional.

Pada wanita hamil dengan diabetes melitus gestasional memiliki resistensi insulin yang lebih tinggi dibanding wanita hamil yang normal dan tidak diimbangi dengan sekresi insulin yang adekuat. Efek pada bayi yang bisa terjadi karena diabetes melitus gesatsional adalah makrosomia dan hipoglikemia yang mendadak pada neonatus ${ }^{13}$.

Oleh karena itu, untuk mengimbangi efek dari suplemen zat besi terhadap sel beta pankreas, dibutuhkan antioksidan yang berperan dalam mengatasi radikal bebas. Salah satu antioksidan yang bisa digunakan adalah vitamin $C$. Vitamin $C$ berperan dalam melindungi sel dari radikal bebas. Hal ini didukung oleh penelitian oleh Rahmawati pada tahun 2015 yang menunjukkan bahwa pemberian vitamin $\mathrm{C}$ yang terdapat pada 
belimbing wuluh dapat menurunkan kadar glukosa pada tikus yang mengalami hiperglikemia ${ }^{14}$.

\section{SIMPULAN}

Pemberian suplementasi besi dosis tinggi dapat menurunkan jumlah sel beta pankreas tikus bunting. Dosis efektif suplementasi besi dalam menurunkan jumlah sel beta pankreas tikus putih (Rattus Norvegicus) adalah dosis 1 yaitu $0,54 \mathrm{mg} / \mathrm{hari}$.

\section{DAFTAR PUSTAKA}

1. Fikawati, Sandra dkk., 2016. Gizi Ibu dan Bayi. Depok: Raja Grafindo Persada

2. Pietrangelo A. 2004. Hereditary hemochromatosis - a new look at an old disease. New England Journal of Medicine

3. Murray, R. K., Granner, D. K., \& Rodwell, V. W. Biokimia harper (27 ed.). Jakarta: Buku Kedokteran EGC; 2009

4. Halliwell B, Gutteridge JM. 1999. Free radicals in medicine and biology. 2nd ed. Oxford: Clarendon Press

5. Cario $\mathrm{H}$, Holl RW, Debatin KM, Kohne E. 2003. Insulin sensitivity and beta-cell secretion in thalassaemia major with secondary haemochromatosis: assessment by oral glucose tolerance test. Eur $\mathrm{J}$ Pediatr.

6. Robertson dkk., 2003. Glucose toxicity in beta-cells: type 2 diabetes, good radicals gone bad, and the glutathione connection. Diabetes

7. Crielaard, Bart J dkk,. 2017. Reviews Targeting Iron Metabolism in Drug Discovery and Delivery. Netherlands : Macmillan Publishers Limited

8. Syamsudin. 2013. Nutrasetikal. Yogyakarta: Graha IImu

9. Wang, Jingjing, Wang Hongjung. 2017. Review Article Oxidative
Stress in Pancreatic Beta Cell Regeneration. USA : Department of Surgery, Medical University of South Carolina

10. Sa'diyah, Chalimatus. 2016. Studi tentang Pengaruh Paparan Asap Rokok dengan Biofilter Berbahan Cengkeh (Syzigium aromaticum) dan Daun Kelor (Moringa oleifera L.) terhadap Kadar Glukosa Darah dan Histologi Pankreas Mencit (Mus musculus) Diabetes Mellitus. Fakultas Sains dan Teknologi. Universitas Islam Negeri Maulana Malik Ibrahim. Malang

11. Suarsana, Nyoman dkk., 2010. Profil Glukosa Darah dan Ultrastruktur Sel Beta Pankreas Tikus yang Diinduksi Senyawa Aloksan. Fakultas Kedokteran Hewan Universitas Udayana, Bali

12. Mutiyani, Mira dkk,. 2013. Efek Diet Tinggi Karbohidrat dan Diet Tinggi Lemak terhadap Kadar Glukosa Darah dan Kepadatan Sel Beta Pankreas pada Tikus Wistar. Indonesian Journal of Human Nutrition

13. Cunningham $F$, Leveno $\mathrm{K}$, Bloom S, Hauth J, Rouse D, Spong C. Maternal Physiology. Williams Obstetrics. 23rd ed. McGraw-Hill; 2010. p. 111

14. Rahmawati, Rikhana Dwi.2015. Pengaruh Pemberian Sari Buah Belimbing Wuluh (Averrhoa Bilimbi L.) Terhadap Kadar Glukosa Darah Tikus Sprague Dawley. Fakultas Kedokteran Universitas 